\title{
A Dashboard for Foreign Investors to set up FPI's in India
}

\author{
K Jhansi ${ }^{1}$, M.Sai Divya Vandana ${ }^{2}$, Ch.Sekhar ${ }^{3}$ \\ Department of CSE, Vignan's Institute of Information Technology (Autonomous), \\ Visakhapatnam, AP, India, \\ ${ }^{1}$ jhansi.kollipaka@gmail.com, ${ }^{3}$ sekhar1203@gmail.com
}

\begin{abstract}
The main purpose of the paper is to increase the funds from the foreign investors in the agricultural sector. This directly improves the economy of India giving the fruitful results. So the complete database about the crops and its yield are provided for the foreign investors to set up FPI's in India. The specific feature of the dashboard is that the paper also provides the single desk portal system (policy) which aims to create the conductive ecosystem to provide all clearances required to set up industry within a stipulated amount of time. In addition to these facilities paper also provides information about the transportation and export data source for every required crop. Alongside these arrangements, venture likewise incorporates the Hyper Food Malls which interface agriculture creation to the market by uniting farmers, processors and retailers.
\end{abstract}

Keywords: FPI, Agriculture, Food parks

\section{Introduction}

Presently our nation "India" stood the second position in the world's maker of sustenance besides China and has the capability of being the greatest using the nourishment and horticultural part. The Food Processing business is one of the most prominent businesses in India, and it is positioned fifth as far as the generation, utilization, sends out and expected development. The Confederation of Indian Industry (CII) has set up that the nourishments handling areas have the capability of drawing in US\$33 billion of interest in 10 years and create work of 9 million worker days. Food Processing is a vast area that covers the exercises, for example, agribusiness, cultivation, ranch, creature farming and fisheries[1].

The Ministry of Food Processing, Government of India, shows the accompanying fragments inside the Food Processing Industry[2]:

Daily foods are grown from the ground preparing

Grain Processing

Meat and Poultry Processing

Fisheries

Consumer Food including bundled nourishments, refreshments and bundled drinking water.

\subsection{FOOD PROCESSING IS IMPORTANT?}


India Food Processing Industry is assessed at $\$ 135$ billion industry which is creating at around $8 \%$ consistently. This improvement rate is basically more than green advancement rate which remains around 4\%. These signs exhibit toward astounding advance toward sustenance planning from standard ways. Total national output by getting ready constitute around $10 \%$ that of cultivating. In any case, given capacity of India, this is an underachievement[3].

India has around 26 sorts of different climatic conditions, 46 groupings of soils are there in India out of total 60 sorts of soils the world over. 127 'agro climatic zones' have been perceived in India. Also, Indian food is known worldwide for its novel taste and aroma.

India is greatest creator of Pulses, Mangoes, Banana, Milk, ginger, Buffalo meat and second greatest producer of rice, wheat, potato, garlic, cashew nut, groundnut, dry onion, green peas, pumpkin, gourds, cauliflowers, sugarcane, and tea on the planet. We make 17 for every penny of the overall total of vegetables and 14 for each penny by virtue of characteristic items. Around 40 percent of the world's mangoes and 30 for every penny of the world's bananas and papayas are conveyed in India. Further, India has various novel things to offer, for instance, Alphonso Mangoes and wheat of Madhya Pradesh is curiously protein rich[4].

India is net exporter of provincial things. However, regard development of Indian thing stays low. Indian Manufacturers haven't pushed much in regard chain. Say If mangoes are set up in to Mango Juice or crush; it will achieve more regard extension, industry, work, GDP and outside exchange, yet we convey generally mangoes as it might be.

India Food Processing Industry is assessed at $\$ 135$ billion industry which is creating at around $8 \%$ consistently. This advancement rate is inside and out more than provincial improvement rate which remains around 4\%[5]. These signs appear toward awesome advance toward sustenance dealing with from customary ways. Total national output by dealing with constitute around $10 \%$ that of cultivating. In any case, given capacity of India, this is an underachievement.

India has around 26 sorts of different climatic conditions, 46 groupings of soils are there in India out of total 60 sorts of soils the world over. 127 'agro climatic zones' have been perceived in India. Moreover, Indian sustenance is known worldwide for its fascinating taste and scent.

India is greatest creator of Pulses, Mangoes, Banana, Milk, ginger, Buffalo meat and second greatest producer of rice, wheat, potato, garlic, cashew nut, groundnut, dry onion, green peas, pumpkin, gourds, cauliflowers, sugarcane, and tea on the planet[6]. We make 17 for each penny of the overall total of vegetables and 14 for every penny because of natural items. Around 40 percent of the world's mangoes and 30 for every penny of the world's bananas and papayas are conveyed in India. Further, India has various fascinating things to offer, for instance, Alphonso Mangoes and wheat of Madhya Pradesh is especially protein rich.

India is net exporter of country things. In any case, regard development of Indian thing stays low. Indian Manufacturers haven't impelled much in regard chain. Say If mangoes are set up in to Mango Juice or squash; it will achieve more regard extension, industry, business, GDP and outside exchange, be that as it may we convey essentially mangoes as it might be.FPI is work concentrated industry; it can be a response to jobless development of past decade. Right now, just $3 \%$ of business is in FPI, while in created nations it handles $14 \%$ populace. Once more, a great part of the business will be made into rustic India. This can cure issue of pain relocation Growth in coordinate work in the composed nourishment preparing segment remains at $6 \%$ between 2011-12[7].

Also, key geographic area and nearness to sustenance bringing in countries (Middle East and Africa) makes India great for the fare of handled nourishments. 


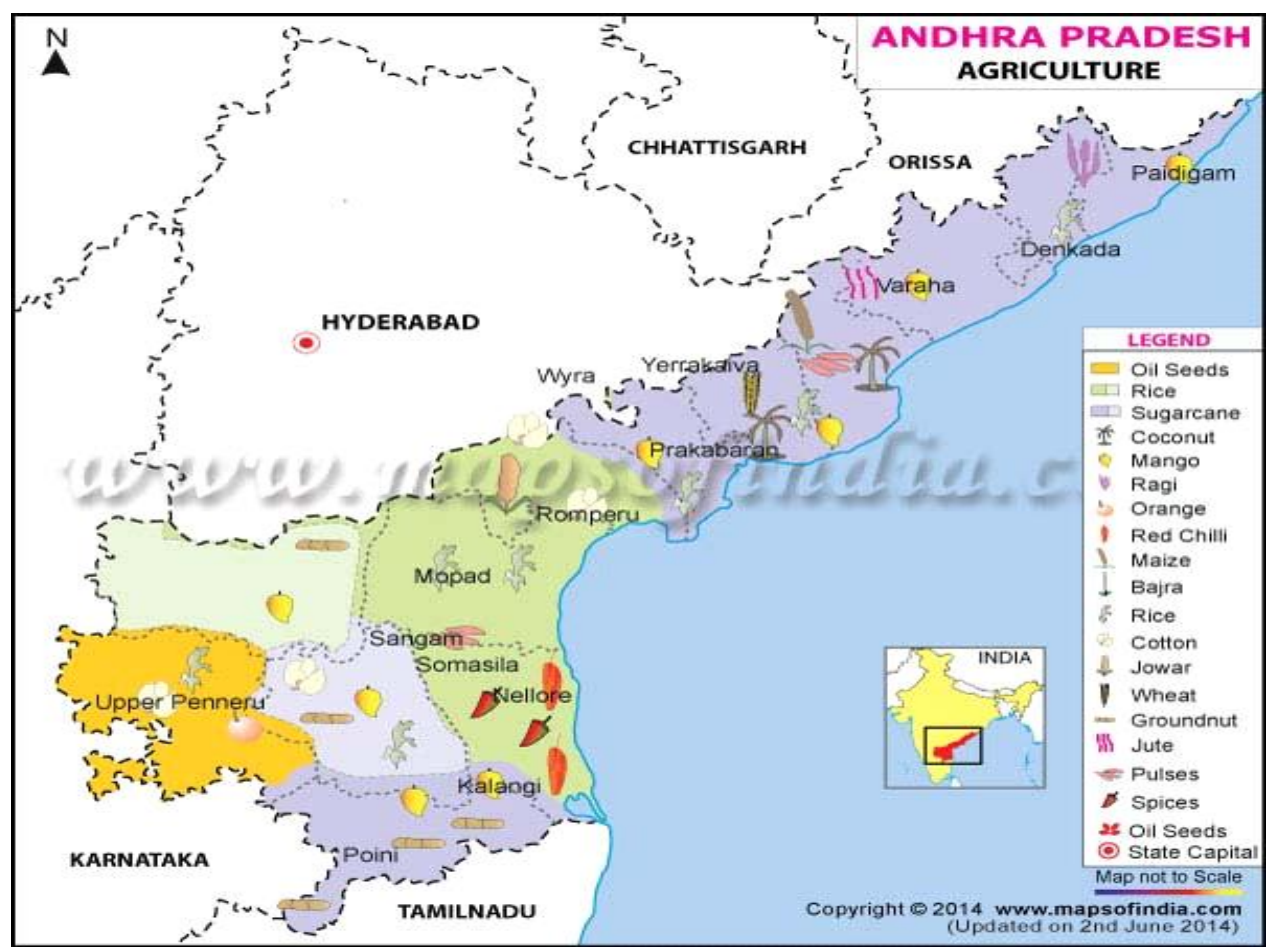

Figure 1. Area Wise availability of various Agri products in AP State

\subsection{Reasons to Invest:}

A rich horticulture asset base-India was positioned No. I on the planet in 2013 as far as creation of Arecanut, Bananas, Castor oil seed, Chickpeas, Chillies and Peppers dry, Ginger, Lemons and limes, Mangoes, Mangosteens, guavas, Millet, Okra, Papayas, Pigeon peas, Meatwild ox, Milk-entire crisp bison and goat, Ghee, spread oil of dairy animals drain, Ghee of bison drain, sesame seed.

India positions second on the planet in the creation of Anise, fennel, coriander, beans-dry, cabbages and different brassicas, cauliflower and broccoli, Egg plants (aubergines), Garlic, Groundnuts with shell, Lentil, Onions dry, Peas green, Potatoes, Pumpkins, Squash and Gourds, Rice/Paddy, Safflower seed, Sugar stick, Tea, Tomatoes, Wheat, Meat-goat, Milk entire crisp dairy animals. Further, India is at third position in the generation of Cashew nuts, with shell, Coconuts, Lettuce and chicory, Nutmeg, mace and cardamoms, Pepper (flute player spp.), Rapeseed[8].

The Country net trimmed region adds up to 194.39 million Hectares, with editing force of $139 \%$. The net watered territory is 66.10 million hectare in 2012-13(P).

An aggregate of 127 agro-climatic zones have been recognized in India.

Strategic geographic area and nearness to nourishment bringing in countries makes India ideal for the fare of prepared sustenances.

Extensive system of nourishment handling preparing, scholastic and research foundations.

42 Mega Food Parks (MFP) are being setup with a speculation of USD 2.38 billion. The parks have around 1250 created plots with fundamental empowered foundation that business visionaries can go up against rent for the setting up of nourishment preparing and subordinate units. As on 25.07.2016, out of 42 MFP ventures 8 ventures have been operationalised.

The cost of skilled labor is moderately low when contrasted with different nations. 
Attractive financial impetuses have been instated by focal and state governments and these incorporate capital sponsorships, assess discounts, deterioration benefits, and additionally lessened custom and extract obligations for prepared sustenance and apparatus.

Major worldwide players in the sustenance space are as of now show in India.

134 cold chain ventures are being setup to create inventory network framework. As on 22.07.2016, out of 134 Cold Chain Projects 87 ventures have been finished.

\section{Problem Statement}

The current status of the prototype developed by our team is in the process of designing the dashboard from the information that has been collected from the requirement analysis. And globally, there are a few websites that are existing in the market such as APEDB, MAKE IN INDIA etc. But the information that is being provided by other sites may not completely satisfy the investor. So the dashboard that our paper will be providing contains each and every bit of information that the foreign investor is searching for. Starting from the required information such as availability, seasonal trends, qualitative analysis, quantitative analysis, water resources and transport resources to the taxes, services and subsidies. Besides, it also provides information about the single desk portal system.

\section{Methodology and Objective}

The main purpose of the paper is to increase the funds from the foreign investors in agricultural sector. This directly improves the economy of India giving the fruitful results. So the complete database about the crops and its yield are provided for the foreign investors in order to set up FPI's in India. The dashboard is mainly divided into Agriculture, Horticulture. Livestock, Fisheries, Investment sectors, Single desk portal, and Updates. For each and every crop, the dashboard is facilitating the common requirements such as Availability which displays the state wise productivity of a particular crop; Seasonal trends which deal with soil conditions, climatic conditions and crop type; Quantitative analysis which show cases production in a pictorial manner; Water resources and Transport services.

Objectives:

Our main objective is to provide

Agri produce

Local industries and traders of food products.

Product wise food clusters.

Processing infrastructure.

Developing a medium between the foreign investors and central government directly.

Proposing single desk portal system to the states which don't have the facility.

Water resources.

Transport services.

Foreign direct investment.

Foreign portfolio investment.

Novelty:

The dashboard includes Single desk system which directly connects the foreign investor with central government in order to get clearances to set up industry.

Provides the information about the different sources of water bodies available for usage of further processing.

If data is maintained by central government, it becomes easy to know the status and investments done in various states. And there is a chance of pushing the investments to the 
states having less FDI's in agri sector by providing the additional subsides. So all states will be equally benefitted.

Information about taxes, services and subsides.

Updates are to be informed to all the registered foreign investors through mails.

Includes the list of local traders for each and every crop in a state.

Provides the facilities of cold storage available in India for various categories of crops.

Provides all the modes of transport and indicates the cheapest as well as fastest means of transport for import and exports.

\subsection{Work Plan}

The work that is to be performed so as to complete the solution for the required proposal strictly follows the software development life cycle.

Requirement Analysis: Initially in this phase the information is to be collected for all the sectors. For each and every crop, the paper is facilitating the common requirements such as availability, seasonal trends, qualitative analysis, quantitative analysis, water resources and transport resources.

Design: In this phase, the gathered information is converted into architectural form. Based on the availability requirements, the dashboard is divided into different modules such as agriculture, horticulture, fisheries, investment sectors, livestock, single portal and updates. The paper is facilitating the relations in between the attributes of different modules which are provided in the dashboard. In case, if there are any duplicates in different modules, the redundancy will be reduced with the help of database techniques.

Coding: In this phase the front end as well as the back end tables are created based on the requirement of respective module coding is done on the basis of CSS, HTML, PHP, JavaScript, and bootstrap. To maintain the information in the database MySQL is used.

Testing: In this phase, the testing is performed for each and every module with different combinations of inputs and validating the functionality of the particular module and cross check with the expected results. If anything fails, bugs will be fixed. For this purpose, the manual testing will be performed, if needed testing tools will be used.

Deployment: In this phase, all the functions provided by the dashboard are brought into action for deployment into the server, configuring the web server, respective ports and setting up the database.

Maintenance: In this phase, time to time backup of the database will take place and if any issues that are to be resolved or any new things needed to be included are done. And if there are any announcements that are to be implemented are incorporated by the end user. Architecture Block Schematic 


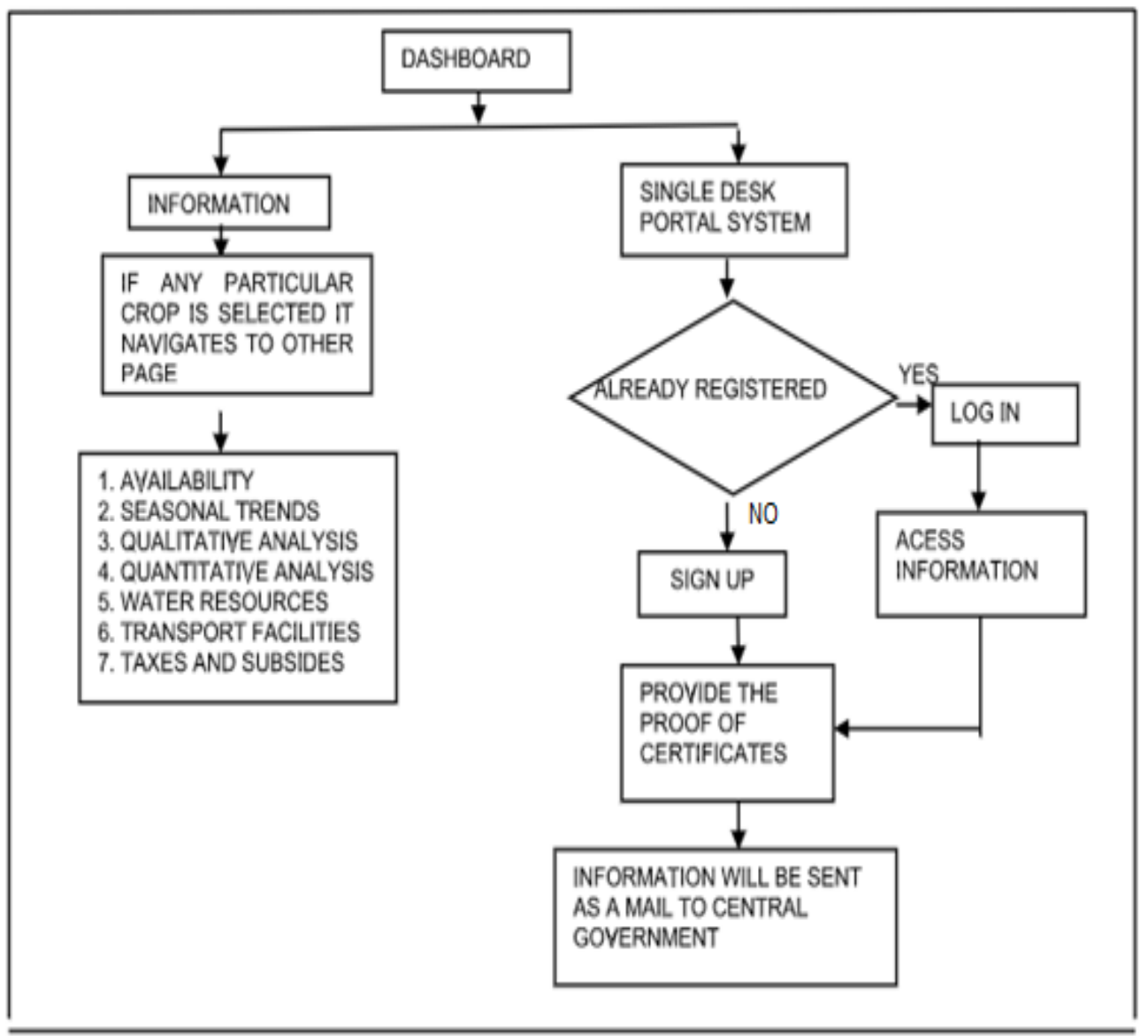

Figure2: Work Flow of the proto type Dash Board 


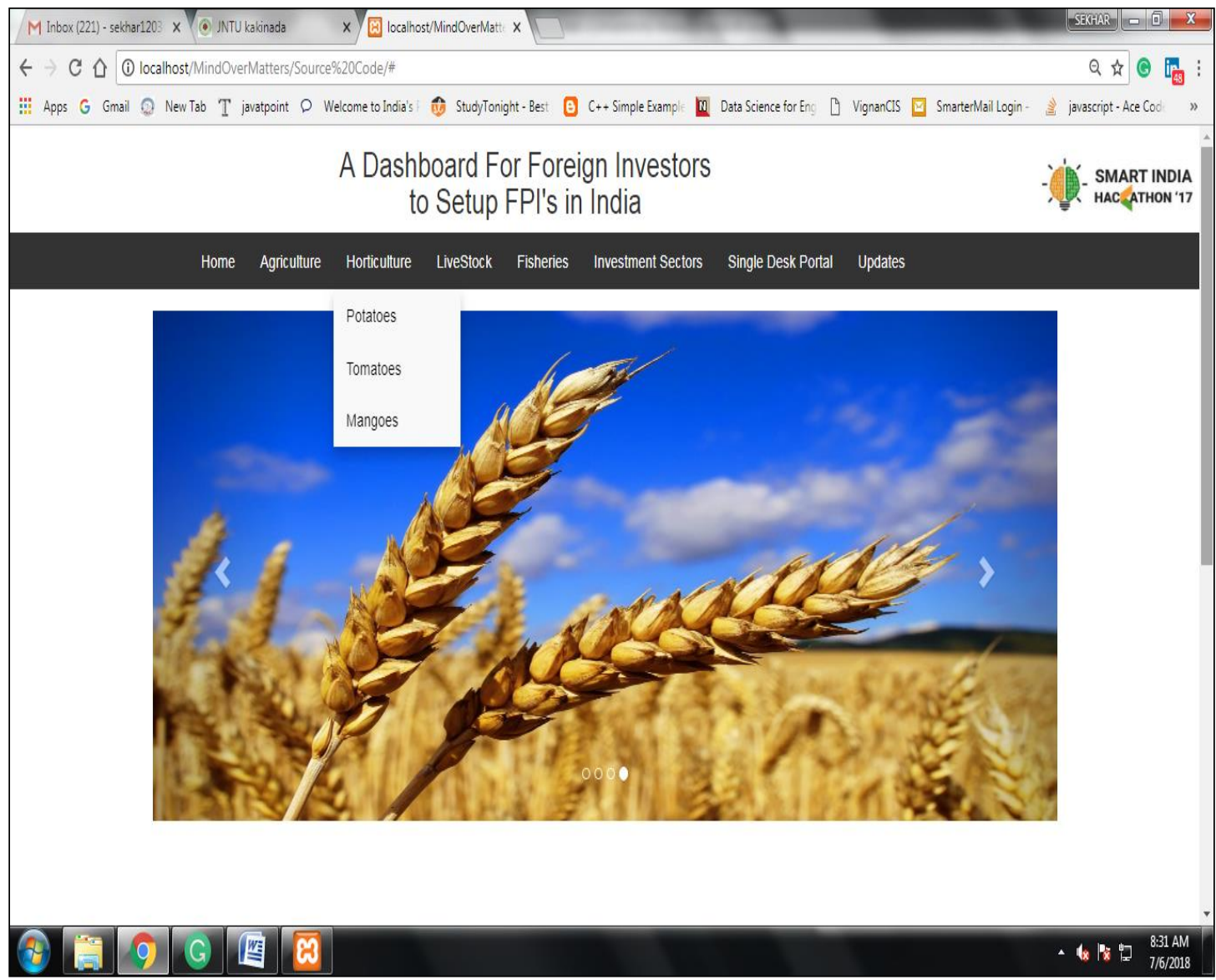

Figure 3. Dashboard Portal for FPI

The above figure shows that web portal for Foreign Investors who are willing to setup there investments in the agricultural sector. This portal is very useful to know the all the information about agricultural harvesting, type of craps, place of the crap. Single desk portal system (policy) which aims to create conductive ecosystem to provide all clearances required to setup industry within stipulated amount of time.

\section{Summary}

In this paper dashboard consists of all the information about crops like its climatic conditions, production, and yield, fertility of the soil, water facilities and subsidies. Paper also provides a registration form where the foreign investors can easily register on the dashboard and that form will be linked to the central government and they will communicate with the investors through proper channels. The specific feature of the dashboard is, that the paper also provides the single desk portal system (policy) which aims to create conductive ecosystem to provide all clearances required to setup industry within stipulated amount of time. In addition to these facilities we also discussed providing of information about the transportation and export data source for every required crop. Along with these provisions, paper also includes the mega food parks which link agriculture production to the market by bringing together farmers, processors and retailers. 


\section{References}

[1] David A. Botwe et al, "A Comparative Study of Web Development Technologies Using Open Source and Proprietary Software", International Journal of Computer Science and Mobile Computing, Vol.4 Issue.2, February (2015), pp. 154-165

[2] Punam Kumari and Rainu Nandal, "A Research Paper on Website Development Optimization Using Xampp/PHP”, International Journal of Advanced Research in Computer Science, Vol. 8, No. 5, May-June (2017)

[3] Leff, A., \& Rayfield, J.T., "Web-Application Development Using the Model-View-Controller Design Pattern", the Fifth IEEE International Enterprise Distributed Object Computing Conference, pp.118-127 (2001) DOI: 10.1109/EDOC.2001.950428

[4] K. Deepa, Dr. N. Sujatha, "Analysis and Detection of Weeds in Agricultural Area using various Image Segmentation Algorithms”, IJSER, vol.5, no.7, ISSN (Online): 2347-3878. pp.256-260 (2017)

[5] Ampong - Nyarko, K. \& De Datta, S.K. A handbook for weed control in Paddy plant. Paddy Research Institute, Manila, Phillippines. (1991).

[6] MAKE IN INDIA- http://www.makeinindia.com/policy/foreign-direct-investment

[7] TAXES AND SUBSIDIES-/www.yourarticlelibrary.com/agriculture/agricultural-subsidies-kinds-ofagricultural-subsidies-in-india/40242/

[8] Cake Software Foundation, CakePHP Overview, CakePHP Cookbook Documentation, pp.45-50 (2014) 